Oswald, E.T. Theoretical overview of successional considerations in vegetation management. 66(4): 361-365.

Pfatzgraf, Jacques. See Bégin, Jean et al.

Pick, R.D. See Gillis, M.D. et al.

Pierpoint, Geoffrey. See Burger, Dys.

Pineau, Marius. See Bégin, Jean et al.

Pineau, Marius. See Bélanger, Louis et al.

Polzin, T. See Moore, W.

Popovich, Stevo. See Labrecque, Michel.

Price, Colin. The allowable burn effect: Does carbon fixing offer a new escape from the bogey of compound interest. 66(6): 572-578.

Reed, F.L.C. Canada's second century of forestry: closing the gap between promise and performance. 66(5): 447-453.

Richard, Yvon. See Robitaille, Lise et al.

Roberts, Donald G. See Baker, Barbara.

Robitaille, Lise, Gilles Sheedy and Yvon Richard. Effets de l'éclaircie précommerciale et de la fertilisation sur un gaulis de 10 ans à dominance de bouleau jaune. 65(5): 487-493.

Rufelds, Carla. The role of CIDA in international forestry development. Le role de l'ACDI dans le développement forestier international. 66(3): 219-235.

Schooley, H.O. See Caron, G.E. et al.

Schuler, Albert T. and J.K. Miel. Markets, products and technology in the 21 st century - a Canadian solid wood products perspective. 66(6): 567-571.

Sedjo, Roger A. Economic wood supply - problems and opportunities: choices for Canada's forest industry. 66(1): 32-34.

Sedjo, Roger A. Comments on "The potential for integrated resource management with intensive or extensive forest management: reconciling vision with reality." 66(5): 461-462.

Sharma, K.K. See Kumar, Prem et al.

Sheedy, Gilles. See Robitaille, Lise et al.

Snider, Edward H. Canadian accomplishments in pulp and paper research, 1805-1990. 66(2): 156-164.

Strell, W.M. See von Althen, F.W.

Steneker, G.A. Forestry Canada's international relations 66(3): 250-252.

Strang, R.M. Forestry management and education. 66(4): 344-345.

Thomas, R. The Jiagedaqi Project: forest fire control in China. 66(3): 266-270.

Titus, Stephen J. See Johnson, Allen F. et al.

Titus, Stephen J. See Morton, R.F. et al.

Tomlinson, Jean. Rayonnement de la Faculté de foresterie et de géomatique [Laval] sur la scéne internationale. 66(3): 260-265.

van Frankenhuyzen, Kees. Development and current status of Bacillus thuringrensis for control of defoliating forest insects. 66(5): 498-507.

VanNest, Terry. See Woodard, Paul M.

Van Wagner, C.E. Six decades of forest fire science in Canada. 66(2): 133-142.

von Althen, F.W. and W.M. Strell. A red pine case history: development of the Rockland plantation from 1914-1986. 66(6): 606-610.

Walker, John L. Traditional sustained yield management: problems and opportunities. 66(1): 20-24.

Wallace, D. Forest entomology or entomology in the forest? Canadian research and development. 66(2): 120-126.

Wang, B.S.P. See Caron, G.E. et al.

Wang, B.S.P. See Case, Boyd.

Webb, Derek. Research for people - IDRC's experience in forestry research. 66(3): 237-240.

Weetman, G.F. See Doucet, René.

Woodard, Paul M. and Terry VanNest. Winter burning bighorn sheep range - a proposed strategy. 66(5): 473-477.

Woodard, Paul M. See Johnson, Allen F. et al.

Worrall, John. Subalpine larch: oldest trees in Canada 66(5): 478-479.

\title{
Editors and Reviewers - The Forestry Chronicle, Volume 66, 1990
}

This is the last issue of The Forestry Chronicle that I shall edit. I have enjoyed my seven years as editor, but it is time to give others the opportunity to bring new ideas and energy to the job. I had intended to write an editorial on the trials, tribulations and joys that the editorship affords, but unfortunately a minor illness laid me low as the Chronicle's deadline approached. However I do wish to thank Doug Redmond and Tim Fenton (former and current Production Manager) and all the Associate Editors for their unselfish efforts on behalf of the Chronicle. I hope that you will give the new editors, Jim Cayford and Darwin Burgess, the same support that you gave to me. Finally, I wish to thank the following reviewers and apologize to those whose names I have missed.

\section{I.C.M. Place}

Archambault, L.

Arnolt, J.T.

Beck, James

Bégin, Jean

Bellefleur, Pierre

Bolghari, H.

Bonnor, G.M.

Brown, J.L.

Clark, W.

Coffey, D.

Cunia, $\mathrm{T}$.

Dickison, R.

Dion, Léopold

Duchesne, André
Edwards, I.K.

Fayle, D.C.

Gagnon, Réjean

Gravellines, L.

Hallet, R.

Head, D.A.

Hiner, T.G.

Jacques, R.

Karaim, Brian

Ker, M.

Krause, $\mathrm{H}$.

Laroque, G.

Lavallée, André
Lavender, D.

Loiffers, Victor

Lepage, $M$.

Lougheed, W.H.

MacDonald, A.

Magnussen, S.

Marshall, J.

Martell, D.

McRae, D.

Migneault, M.

Moore, $\mathrm{T}$.

Murtha, P.

Needham, E.
Nigh, G.

Peine, $\mathrm{H}$.

Powell, G.

Raphael, M.

Reed, D.

Roberts, M.

Ruel, Jean-Claude

Savard, J.P.

Shaw, J.

Strickland, M.

Townsend, G.

Van Wagner, C.A.

Weetman, G.F. 